\section{Universitetet i Oslo www.med.uio.no/disputaser/}

Silvia Rollefstad, ph.d. Novel results from cardiovascular prevention in patients with inflammatory joint diseases. Utgår fra Institutt for klinisk medisin. Disputas 5.2. 2015.

Bedømmelseskomité: John J.P. Kastelein, Academic Medical Center, University of Amsterdam, Nederland, Cynthia S. Crowson, Mayo Clinic, Rochester, USA, og Torbjørn Omland, Institutt for klinisk medisin, Universitetet i Oslo.

Veiledere: Anne Grete Semb, Tore Kristian Kvien og Terje Rolf Pedersen.

Synne Øien Stensland, ph.d. Interpersonal violence and health in adolescents. Violence, sexual abuse and bullying in relation to recurrent headache \& overweight, psychosocial \& lifestyle factors, in a population-based cohort of adolescents. Utgår fra Institutt for klinisk medisin. Disputas 5.2. 2015.

Bedømmelseskomité: Kathleen Ries Merikangas, Genetic Epidemiology Research Branch, National Institute of Mental Health, Bethesda, MD, USA, Ulrich Schnyder, Department of Psychiatry and Psychotherapy, University Hospital Zurich, Sveits, og Anne Margrethe Myhre, Institutt for klinisk medisin, Universitetet i Oslo.

Veiledere: Grete Dyb og Siri Thoresen.
Hans Lövdahl, ph.d. Phenomenological and cognitive aspects of recurrent brief depression. Utgår fra Institutt for klinisk medisin. Disputas 6.2. 2015.

Bedømmelseskomité: Jules Angst, Department of Psychiatry, Psychotherapy and Psychosomatics, Psychiatric Hospital, University of Zurich, Sveits, Lars von Knorring, Institutionen för neurovetenskap, Psykiatri, Uppsala Universitet, Sverige, og Toril Dammen, Institutt for medisinske basalfag, Universitetet i Oslo. Veileder: Ulrik Fredrik Malt.

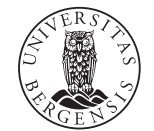

Universitetet i Bergen www.uib.no/info/dr_grad/

Ida Wiig Sørensen, ph.d. Molecular characterisation of integrin $\alpha 11$ function - in vitro and in vivo studies. Utgår fra Institutt for biomedisin. Disputas 12.2. 2015.

Bedømmelseskomité: Matthias Chiquet, University of Bern, Sveits, Staffan Johansson, Uppsala Universitet, Sverige, og Silke Appel, Universitetet i Bergen.

Veileder: Donald Gullberg.

\title{
Øivind Ekeberg utnevnt til ridder av 1. klasse
}

\author{
Professor Øivind Ekeberg (f. 1945) er utnevnt til ridder av 1. klasse av St. Olavs Orden for sin innsats for \\ medisin og samfunnsliv.
}

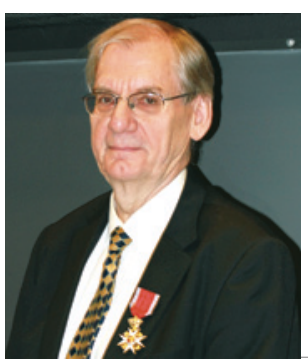

Foto: Erik Holt,

Universitetet i Oslo

Ekeberg er overlege i psykiatri ved Akuttmedisinsk avdeling, Oslo universitetssykehus, Ullevål og professor II ved Avdeling for atferdsvitenskap, Det medisinske fakultet, Universitetet i Oslo.

Allerede som ung lege ble Øivind Ekeberg særlig interessert i pasienter med selvmordsproblematikk. Ved Ullevål sykehus var han med på å bygge opp en egen observasjonsavdeling for pasienter innlagt med selvpåført forgiftning. Ekeberg var en pådriver for at alle pasienter som var innlagt i sykehus pga. selvmordsatferd skulle vurderes og henvises til adekvat oppfølging etter utskrivning. Ekeberg har publisert en serie arbeider om gruppens kjennetegn, forløp og risiko for nye selvmordsforsøk. På oppdrag fra Helsedirektoratet i 1993 utarbeidet han et av de første nasjonale selvmordsforebyggende programmene i verden. I 2013 ble han tildelt Ringel Service Award for «outstanding contributions in the field of suicide prevention» (http://tidsskriftet.no/article/3069754).
Ekeberg har gjort en rekke studier av og laget et kursopplegg for mennesker med flyskrekk. Dette førte til hans doktorgradsarbeid (1991), som var den første doktoravhandlingen om emnet i verden.

Ekeberg har både klinisk og forskningsmessig engasjert seg i psykososiale aspekter ved somatisk sykdom og etter alvorlige kroppstraumer. Han har også vært opptatt av å støtte ansatte som har vært involvert i meldepliktige forhold, særlig etter medieeksponering.

Ved Universitetet i Oslo har han vært studiedekanus og hatt sentrale verv bl.a. i forbindelse med ny studieordning og oppstart av forskerlinjen. Han har mer enn 300 publikasjoner i vitenskapelige tidsskrifter eller som bokkapitler, har veiledet 21 doktorgradskandidater og vært medlem av 34 komiteer for vurdering av professorater og doktorgrader.

Samfunnsengasjementet har kommet til uttrykk som medlem av kommunestyre og fylkesting, der han særlig engasjerte seg i helseog sosialpolitiske saker. Han var i ti år leder av Bærum Schakselskaps Ungdom.

Les portrettintervjuet med Øivind Ekeberg i Tidsskriftet nr. 2/2012 (http://tidsskriftet.no/article/2204607)

\section{Erlend Hem}

erlend.hem@medisin.uio.no 